\title{
Comparative Bioinformatics Analysis of the Chloroplast Genomes of a Wild Diploid Gossypium and Two Cultivated Allotetraploid Species
}

\author{
Farshid Talat 1,2,*, Kunbo Wang ${ }^{2}$ \\ ${ }^{1}$ West Azerbaijan Agricultural and Natural Resources Research Center, AREEO, Urmia, Iran \\ ${ }^{2}$ Cotton Research Institute, Chinese Academy of Agricultural Sciences/Key Laboratory of Cotton Genetic Improvement, \\ Ministry of Agriculture, Anyang 455000, Henan, China \\ ${ }^{*}$ Corresponding author: Farshid Talat, West Azerbaijan Agricultural and NaturalResources Research Center, Urmia, Iran. Tel: +98-4432722197, Fax: +98- \\ 4432722221, E-mail: farshid.talat@gmail.com
}

Received: January 07, 2015; Revised: June 27, 2015; Accepted: August 27, 2015

Background: Gossypium thurberi is a wild diploid species that has been used to improve cultivated allotetraploid cotton. G. thurberi belongs to D genome, which is an important wild bio-source for the cotton breeding and genetic research. To a certain degree, chloroplast DNA sequence information are a versatile tool for species identification and phylogenetic implications in plants. Different chloroplast loci have been utilized for evaluating phylogenetic relationships at each classification level among plant species, including at the interspecies and intraspecies levels. Present study was conducted in order to analyse the sequence of its chloroplast.

Objectives: Present study was conducted to study and compare the complete chloroplast sequence of G. thurberi, analyses of its genome structure, gene content and organization, repeat sequence and codon usage and comparison with two cultivated allotetraploid sequenced cotton species.

Materials and Methods: The available sequence was assembled by DNAman (Version 8.1.2.378). Gene annotation was mainly performed by DOGMA. The map of genome structure and gene distribution were carried out using OGDRAW V1.1. Relative synonymous codon usage (RSCU) of different codons in each gene sample was calculated by codonW in Mobyle. To determine the repeat sequence and location, an online version of REPuter was used.

Results: The G. thurberi chloroplast $(c p)$ genome is 160264 bp in length with conserved quadripartite structure. Single copy region of cp genome is separated by the two inverted regions. The large single copy region is $88,737 \mathrm{bp}$, and the small single copy region is $20,271 \mathrm{bp}$ whereas the inverted repeat is $25,628 \mathrm{bp}$ each. The plastidic genome has 113 single genes and 20 duplicated genes. The singletones encode 79 proteins, 4 ribosomal RNA genes and 30 transfer RNA genes.

Conclusions: Amongst all plastidic genes only 18 genes appeared to have 1-2 introns and when compared with cpDNA of two cultivated allotetraploid, rps18 was the only duplicated gene in G.thurberi. Despite the high level of conservation in cp genome SSRs, these are useful in analysis of genetic diversity due to their greater efficiency as opposed to genomic SSRs. Low GC content is a significant feature of plastidic genomes, which is possibly formed after endosymbiosis by DNA replication and repair.

Keywords: Chloroplast genome, Complete sequence, Gossypium thurberi

\section{Background}

Most plastidic genomes have four regions, namely large single copy region (LSC, $80 \mathrm{~Kb}$ ), small single copy region $(\mathrm{SSC}, 20 \mathrm{~kb})$ and two inverted repeat regions (IR, $25 \mathrm{~kb}$ ). The single copy region is separated by two IRs. This structural conservation however breaks in some plants sauch as Vicia faba (1) and Cryptomeria japonica $(2,3)$ by loss of an IR, and in Euglena gracilis that has three tandem repeats (4).

Variations among different species provide large information for the phylogenetic studies. Chloroplasts have low mutation rate with great deal of conservation in their genome size and structure, gene content and organization. Few differences have been reported in the same species, but significant differences could be detected between the different species in genome size and gene orientation (5). It has been reported that, chloroplast genes like $16 S, 23 S, n d h B, p s b A, p s b D$, $p s a B$, pas $A, p s b C, p s b B$ and $r b c L$ are appropriate to study the relationship among higher plants; ycf1, ycf2, accD, matK, rpoC2 and $\mathrm{ndhF}$ are more suitable to study the relationship of the close species (5).

Transplastomics have proved to be a powerful tool to improve the plant genetic architecture with high 
expression of the foreign protein, low risk of the pollen pollution (6) and no gene silencing. Therefore and In addition to phylogenetic analysis based on plastidic genomes, it is imperative to understand the chloroplast genome in order to logically design our next generation transplastomics. Accordingly, chloroplast genomes of many species have been sequenced (7-14).

\section{Objectives}

Gossypium includes 52 species that are divided to eight diploid genome A-G and $\mathrm{K}(2 \mathrm{n}=26)$, and one allotetraploid genome (AADD, $2 \mathrm{n}=52$ ). G. barbadense and G. hirsutum are extensively cultivated in the world and their chloroplast genome sequences have been published. G. thurberi belongs to D genome, which is an important wild bio-source for the cotton breeding and genetic research. Present study was conducted to study and compare the complete chloroplast sequence of G. thurberi, analyses of its genome structure, gene content and organization, repeat sequence and codon usage. Meanwhile the comparison of the three sequenced cotton species was performed.

\section{Materials and Methods}

\subsection{Chloroplast Sequence}

Compleate chloroplast genome sequence of Gossypium thurberi with accession number NC_015204.1 downloaded from NCBI (http://www.ncbi.nlm.nih.gov/nuccore/?term=Gossy pium thurberi).

\subsection{Genome Assembly and Gene Annotation}

The available sequence was assembled by

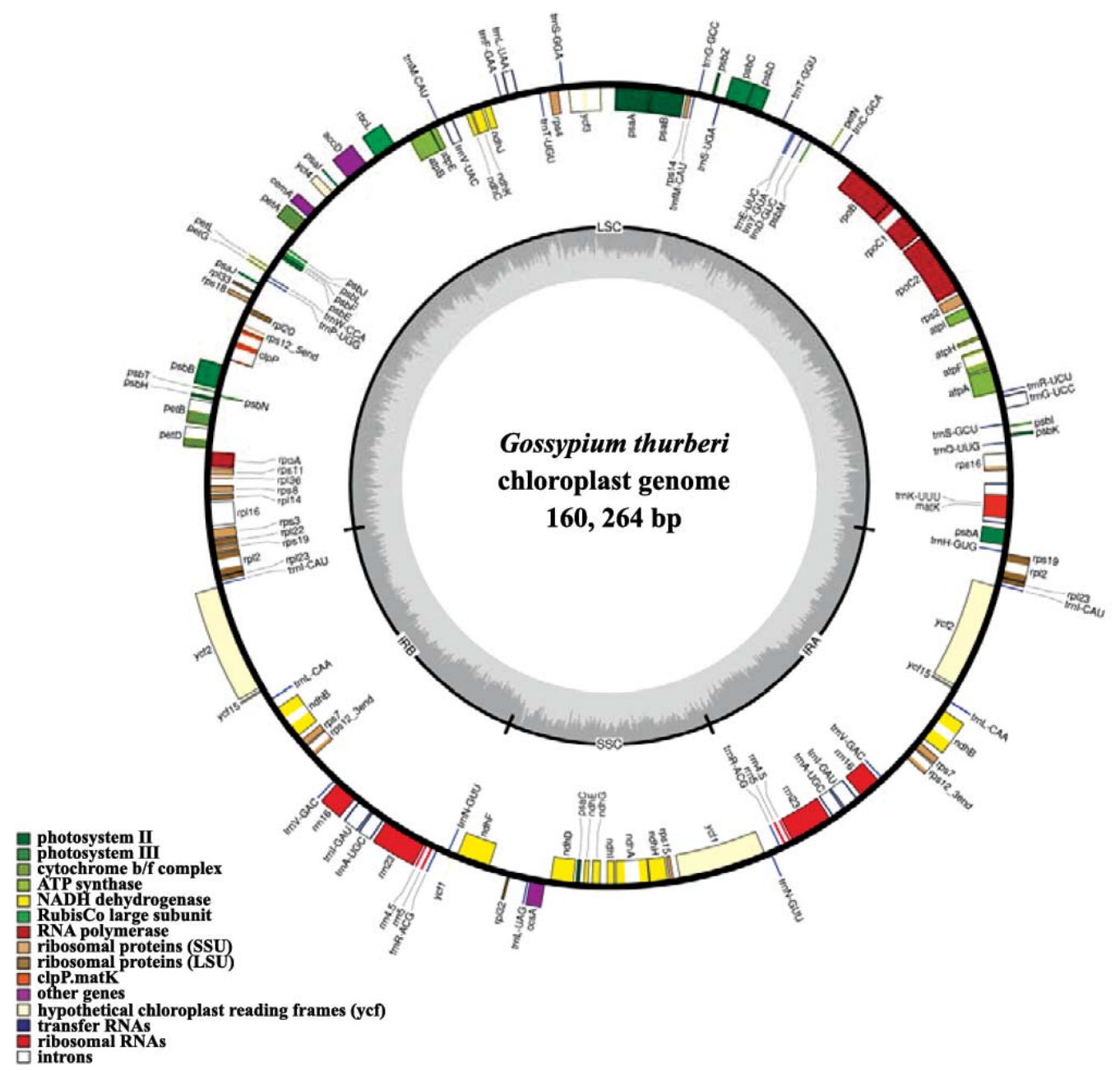

Figure 1. Gossypium thureri chloroplast genome structure and gene organization

Note: genes shown outside of the circle transcribed anticlockwise and shown inside of the circle transcribed clockwise. tRNA genes are shown by 1 letter of the coded amino acid followed by anticodon (genome map was created by using OGDRAW V 1.1, Lohse, 2007) 
Table 1. Repeat sequences detected in chloroplast genome of G. thurberi

\begin{tabular}{|c|c|c|c|}
\hline Number & Size(bp) & Location & Match direction \\
\hline 1 & 30 & intron, IGS & $\mathrm{C}$ \\
\hline 2 & 32 & IGS & $\mathrm{C}$ \\
\hline 3 & 30 & IGS & $\mathrm{F}$ \\
\hline 4 & 30 & IGS-trnS, & $\mathrm{F}$ \\
\hline 5 & 30 & Itron, IGS & $\mathrm{F}$ \\
\hline 6 & 30 & ycf2 & $\mathrm{F}$ \\
\hline 7 & 31 & IGS & $\mathrm{F}$ \\
\hline 8 & 31 & IGS & $\mathrm{F}$ \\
\hline 9 & 31 & IGS & $\mathrm{F}$ \\
\hline 10 & 32 & IGS & $\mathrm{F}$ \\
\hline 11 & 33 & IGS & $\mathrm{F}$ \\
\hline 12 & 34 & IGS & $\mathrm{F}$ \\
\hline 13 & 34 & IGS & $\mathrm{F}$ \\
\hline 14 & 34 & IGS & $\mathrm{F}$ \\
\hline 15 & 34 & IGS & $\mathrm{F}$ \\
\hline 16 & 34 & ycf2 & $\mathrm{F}$ \\
\hline 17 & 34 & ycf2 & $\mathrm{F}$ \\
\hline 18 & 35 & Intron & $\mathrm{F}$ \\
\hline 19 & 36 & Intron, IGS & $\mathrm{F}$ \\
\hline 20 & 38 & IGS, Intron & $\mathrm{F}$ \\
\hline 21 & 38 & ycf2 & $\mathrm{F}$ \\
\hline 22 & 38 & ycf2 & $\mathrm{F}$ \\
\hline 23 & 38 & ycf2 & $\mathrm{F}$ \\
\hline 24 & 41 & Intron & $\mathrm{F}$ \\
\hline 25 & 43 & IGC & $\mathrm{F}$ \\
\hline 26 & 47 & ycf2 & $\mathrm{F}$ \\
\hline 27 & 52 & ycf2 & $\mathrm{F}$ \\
\hline 28 & 64 & ycf2 & $\mathrm{F}$ \\
\hline 29 & 64 & ycf2 & $\mathrm{F}$ \\
\hline 30 & 72 & psaB, psaA & $\mathrm{F}$ \\
\hline 31 & 30 & trnS & $\mathrm{P}$ \\
\hline 32 & 31 & IGS & $\mathrm{P}$ \\
\hline 33 & 31 & IGS & $\mathrm{P}$ \\
\hline 34 & 31 & IGS & $\mathrm{P}$ \\
\hline 35 & 34 & IGS & $\mathrm{P}$ \\
\hline 36 & 34 & ycf2 & $\mathrm{P}$ \\
\hline 37 & 34 & ycf2 & $\mathrm{P}$ \\
\hline 38 & 34 & IGS & $\mathrm{P}$ \\
\hline 39 & 34 & IGS & $P$ \\
\hline 40 & 34 & ycf2 & $\mathrm{P}$ \\
\hline 41 & 34 & ycf2 & $P$ \\
\hline 42 & 36 & Intron, IGS & $\mathrm{P}$ \\
\hline 43 & 38 & Intron, IGS & $\mathrm{P}$ \\
\hline 44 & 38 & ycf2 & $\mathrm{P}$ \\
\hline 45 & 38 & ycf2 & $\mathrm{P}$ \\
\hline 46 & 41 & IGS & $\mathrm{P}$ \\
\hline 47 & 43 & IGS & $P$ \\
\hline 48 & 43 & IGS & $\mathrm{P}$ \\
\hline 49 & 48 & IGS & $\mathrm{P}$ \\
\hline 50 & 52 & ycf2 & $\mathrm{P}$ \\
\hline 51 & 52 & ycf2 & $P$ \\
\hline 52 & 64 & ycf2 & $\mathrm{P}$ \\
\hline 53 & 64 & ycf2 & $\mathrm{P}$ \\
\hline 54 & 30 & ycf1 & $\mathrm{R}$ \\
\hline 55 & 30 & IGS & $\mathrm{R}$ \\
\hline 56 & 30 & IGS & $\mathrm{R}$ \\
\hline 57 & 30 & IGS & $\mathrm{R}$ \\
\hline 58 & 30 & IGS & $\mathrm{R}$ \\
\hline 59 & 31 & IGS & $\mathrm{R}$ \\
\hline
\end{tabular}

Continued in the next column

\begin{tabular}{lccc}
\hline Number & Size(bp) & Location & Match direction \\
\hline 60 & 32 & Intron & $\mathrm{R}$ \\
61 & 32 & IGSS & $\mathrm{R}$ \\
62 & 32 & IGS & $\mathrm{R}$ \\
63 & 33 & IGS & $\mathrm{R}$ \\
64 & 33 & IGS & $\mathrm{R}$ \\
65 & 35 & IGS & $\mathrm{R}$ \\
66 & 38 & IGS & $\mathrm{R}$ \\
\hline
\end{tabular}

Note: IGS represents intergenic spacer sequence. F represents forward (direct) match, $\mathrm{R}$ represents reverse match, $\mathrm{C}$ represents complement match, $\mathrm{P}$ represents palindromic (invert) match

DNAman (Version 8.1.2.378). Gene annotation was mainly performed by DOGMA (Dual Organellar Geno Me Annotator, http://dogma.ccbb.utexas.edu/; Wyman, 2004). DOGMA uses BLAST against 11 plant chloroplast database (Adiantum capillus-veneris, Arabidopsis thaliana, Chlorella vulgaris, Lotus japonicus, Marchantia polymorpha, Mesostigma viride, Nephroselmis olivacea, Nicotiana tabacum, Oenothera elata, Oryza sativa, Pinus thunbergii, Psilotum nudum, Spinacia oleracea, Triticum aestivum, Zea mays). Identity cutoff for protein coding genes was set at $60 \%$. Identity cutoff for RNAs was set at $80 \%$. The map of genome structure and gene distribution were carried out using OGDRAW V1.1 (OrganellarGenomeDRAW, http://ogdraw.mpimpgolm.mpg.de/), which takes a Genbank file or a special accession number (15).

\subsection{Chloroplast Genome Analysis}

Relative synonymous codon usage (RSCU) of different codons in each gene sample was calculated by codonW in Mobyle (http://mobyle.pasteur.fr/cgibin/portal.py). To determine the repeat sequence and location, an online version of REPuter (http://bibiserv. techfak.uni-bielefeld.de/reputer/) was used (16). Searching condition was followed as Saski (3).

\section{Results}

\subsection{Overall Structure}

Chloroplast genome of G. thurberi (Figure 1) has a conserved quadripartite structure. Total genome is a circular DNA molecule of 160,264 bp, which is shorter than G. barbadnese (17) and G. hirsutum (18). The two single copy regions are separated by the two inverted repeats. The whole genome was analyzed (Table 1). The large single copy region is $88,737 \mathrm{bp}$, the small single copy is $20,271 \mathrm{bp}$ and the two inverted repeats are 25 , 
Table 2. Simple sequence repeat (SSR) in G. thurberi chloroplast genome

\begin{tabular}{lccc}
\hline Repeat & $\begin{array}{c}\text { Repeat } \\
\text { sequence }\end{array}$ & Number & Max (bp) \\
\hline mononucleotide & A & 14 & 12 \\
& C & 2 & 13 \\
& T & 32 & 13 \\
dinucleotide & AT & 8 & 12 \\
& CT & 1 & 14 \\
& TA & 5 & 12 \\
trinucleotide & TC & 1 & 10 \\
total & TG & 1 & 10 \\
& AAT & 1 & 12 \\
& ATA & 1 & 12 \\
& TTA & 1 & 12 \\
\hline
\end{tabular}

$628 \mathrm{bp}$ each. The coding region is $91,485 \mathrm{bp}$ in length, accounting for $57.08 \%$ of the whole plastidic genome, which is similar to Gossypium hirsutum by $56.46 \%$ (18), Bambusa oldhamii by $53.4 \%$ (13) and Dendrocalamus latiflorus by $53.4 \%$ (13), genus Megaleranthis 52.4\% (5), genus Alsophila 53.2\% (8). where as it is smaller than Glycine $\max (60 \%)$. $G$. thurberi plastidic genome codes for proteins $(49.76 \%)$, tRNA genes $(1.73 \%)$ and rRNA (5.60\%), similar to Manihot esculenta (19), cucumber (20) and coffee (21). The non-coding region is $70,351 \mathrm{bp}$ in length $(43.90 \%$ of the genome). The proportions of intergenic spacers and intron are $31.15 \%$ and $12.75 \%$, respectively.

\subsection{Repeat Sequence}

Chloroplast genome structures are similar to prokaryotes, it has been considered uncommon to have large scale of repeat sequences in these genomes. Here, PEPuter was used to detect the repeat sequence of cp genome of $G$. thurberi. Four types of repeats were detected; forward (direct) match, reverse match, complements match and palindromic (inverted) match. Sixty six repeats having more than $30 \mathrm{bp}$ in length are listed in (Table 1). There are 2 complementary repeats, 28 forward repeats, 23 inverted repeats and 13 reverse repeats. Most of the repeats are located at ycf 2 and intergenic spacers (IGS), and few located at trnS and introns. The largest repeat is $72 \mathrm{bp}$, which is located at psaB and psaA, while the most of the repeats are 30-

Table 3. Genes coded by G. thurberi chloroplast genome

\begin{tabular}{|c|c|c|}
\hline & Group & Gene name \\
\hline \multirow{7}{*}{ protein gene } & Subunit of Acetyl-CoA-carboxylase & $a c c D$ \\
\hline & Large subunit of rubisco & $r b c L$ \\
\hline & Subunits of NADH-dehydrogenase & $n d h A^{*}, n d h B^{\star \S}, n d h C, n d h D, n d h E, n d h F, n d h G, n d h H, n d h l, n d h J, n d h K$ \\
\hline & Subunits of ATP synthase & $\operatorname{atp} A, \operatorname{atp} B, \operatorname{atp} E, \operatorname{atp} F^{*}$, atpH, atpl \\
\hline & Subunits of cytochrome b/f complex & pet $A$, petB*, pet $D^{*}$, petG, petL, pet $N \operatorname{ccs} A$ \\
\hline & subunits of photosystem I and II & $\begin{array}{c}\text { psaA, psaB, psaC, psal, psaJ, psbA, psbB, psbC, psbD, psbE, psbF, psbH, } \\
\text { psbl, psbJ, psbK, psbL, psbM, psbN,psbT,psbZ }\end{array}$ \\
\hline & DNA dependendt RNA polymerase & $r p o A, r p o B, r p o C 1^{*}, r p o C 2$ \\
\hline \multirow{6}{*}{ RNA gene } & Large subunit of ribosome & $r p / 14, r p / 16^{\star}, r p / 2^{\star \S}, r p / 20, r p / 22, r p / 23 \S, r p / 32, r p / 33, r p / 36$ \\
\hline & Small subunit of ribosome & $\begin{array}{c}r p s 11, r p s 12^{\star} \S, r p s 14, r p s 15^{\star}, r p s 16^{*}, r p s 18, r p s 19 \S, r p s 2, r p s 3, r p s 4, \\
r p s 7 \S, r p s 8\end{array}$ \\
\hline & & $\operatorname{cemA}, \mathrm{clp} P^{\star *}$, matK \\
\hline & & $y c f 1 \S, y c f 15 \S, y c f 2 \S, y c f 3^{\star *}, y c f 4$ \\
\hline & ribosomal RNA gene & \\
\hline & transier RIVA gene & 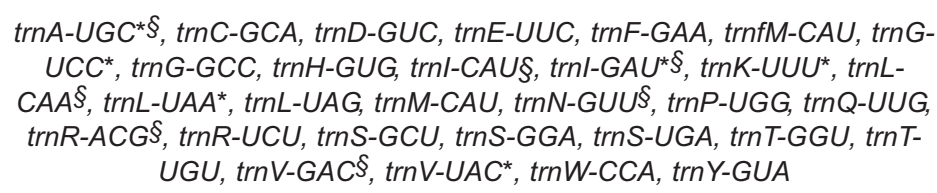 \\
\hline
\end{tabular}

Note: $\S$ reflects gene located in IR; ${ }^{*}$ reflects gene which has one intron; ${ }^{* *}$ reflects gene which has two introns 
Table 4. Codon analysis of G. thurberi chloroplast genes that code for proteins

\begin{tabular}{|c|c|c|c|c|c|c|c|}
\hline AA & Codon & Number & RSCU & AA & Codon & Number & RSCU \\
\hline \multirow[t]{2}{*}{ Phe } & TTT & 908 & 1.33 & Ser & TCT & 498 & 1.71 \\
\hline & TTC & 453 & 0.67 & & TCC & 265 & 0.91 \\
\hline \multirow[t]{6}{*}{ Leu } & TTA & 824 & 1.97 & & TCA & 355 & 1.22 \\
\hline & TTG & 517 & 1.23 & & TCG & 156 & 0.54 \\
\hline & СTT & 506 & 1.21 & Pro & ССТ & 373 & 1.51 \\
\hline & СТС & 153 & 0.37 & & $\mathrm{CCC}$ & 191 & 0.77 \\
\hline & CTA & 350 & 0.83 & & CCA & 272 & 1.1 \\
\hline & CTG & 165 & 0.39 & & CCG & 150 & 0.61 \\
\hline \multirow[t]{3}{*}{ Ile } & ATT & 1000 & 1.5 & Thr & АCT & 479 & 1.56 \\
\hline & ATC & 384 & 0.58 & & ACC & 251 & 0.82 \\
\hline & ATA & 619 & 0.93 & & ACA & 368 & 1.2 \\
\hline Met & ATG & 542 & 1 & & ACG & 129 & 0.42 \\
\hline \multirow[t]{4}{*}{ Val } & GTT & 459 & 1.42 & Ala & GCT & 626 & 1.77 \\
\hline & GTC & 166 & 0.51 & & GCC & 242 & 0.68 \\
\hline & GTA & 479 & 1.48 & & GCA & 359 & 1.02 \\
\hline & GTG & 192 & 0.59 & & GCG & 187 & 0.53 \\
\hline \multirow[t]{2}{*}{ Tyr } & TAT & 713 & 1.61 & Cys & TGT & 190 & 1.52 \\
\hline & TAC & 174 & 0.39 & & TGC & 60 & 0.48 \\
\hline \multirow[t]{2}{*}{ Ter } & TAA & 47 & 1.76 & Ter & TGA & 17 & 0.64 \\
\hline & TAG & 16 & 0.6 & Trp & TGG & 458 & 1 \\
\hline \multirow[t]{2}{*}{ His } & CAT & 464 & 1.48 & Arg & CGT & 307 & 1.32 \\
\hline & CAC & 162 & 0.52 & & CGC & 116 & 0.5 \\
\hline \multirow[t]{2}{*}{ Gln } & CAA & 663 & 1.53 & & CGA & 326 & 1.4 \\
\hline & CAG & 203 & 0.47 & & CGG & 106 & 0.46 \\
\hline \multirow[t]{2}{*}{ Asn } & AAT & 859 & 1.54 & Ser & AGT & 364 & 1.25 \\
\hline & AAC & 253 & 0.46 & & AGC & 107 & 0.37 \\
\hline \multirow[t]{2}{*}{ Lys } & AAA & 909 & 1.51 & Arg & AGA & 390 & 1.68 \\
\hline & AAG & 294 & 0.49 & & AGG & 148 & 0.64 \\
\hline \multirow[t]{2}{*}{ Asp } & GAT & 767 & 1.59 & Gly & GGT & 554 & 1.29 \\
\hline & GAC & 196 & 0.41 & & GGC & 195 & 0.45 \\
\hline \multirow[t]{2}{*}{ Glu } & GAA & 926 & 1.5 & & GGA & 653 & 1.52 \\
\hline & GAG & 307 & 0.5 & & GGG & 313 & 0.73 \\
\hline
\end{tabular}

Note: Codon shown in bold represents RSCU value $>1$

$40 \mathrm{bp}$. In addition to the four types of repeats, there are few simple sequence repeats (SSRs).

Simple sequence repeats were screened in $G$. thurberi chloroplast genome and $67 \mathrm{cpSSRs}(\geq 10 \mathrm{bp})$ were obtained. Most of the SSRs are mononucleotide repeats, while 16 dinucleotide repeats and 3 trinucleotide repeats. The longest repeat is the repeat of "CT", which is $14 \mathrm{bp}$, but the most of the repeats are C and $\mathrm{T}$ having $13 \mathrm{bp}$ (Table 2).

\subsection{Gene Content and Codon Usage}

Genes coded by the $\mathrm{cp}$ of $G$. thurberi are listed (Table 3). Among the total 79 protein coded genes, there are 4 rRNA genes, 30 tRNA genes and 113 single genes; out of which 20 genes are duplicated, locating at IR. According to the gene function, all genes can be classified as genes of the functional genetic system, the photosynthetic system, the biosynthesis and some with unknown function. In G. thurberi cp genome, five genes with unknown function (ycf gene) were detected and considered as to be essential in plants, which were highly conserved between species (22). Intrestingly, two genes, namely rps 12 has an intron (5). rps 12 was separated (by an intron) into two fragments with one exon locating at LSC $\left(5^{\prime}\right.$-end) and the other at $3^{\prime}$-end at IR. mat $K$ is $1.5 \mathrm{Kbp}$ in length, and was found in the intron of $\operatorname{trnK}-U U U$, which is the only gene located in an intron and encodes maturase $\mathrm{K}$. This gene has both conserved and variable fragments (23). Thus, it is frequently used in phylogenetic studies $(24,25,23,14)$.

The codon usage was analyzed (Table 4). ATG and TGG code for methionine as the start codon and tryptophane, respectively with RSCU value $=1$. RSCU val- 
ues of the three terminal codons TAA, TGA and TAG are 1.76, 0.64 and 0.6, respectively. Accoding to RSCU value, $G$. thurberi prefers TAA as its stop codon. The RSCU values grater than 1 indicates greater codon frequency. Most of the codons prefer A or $\mathrm{T}$ at the third position. The analysis of the composition for the codons showed that $\mathrm{A}+\mathrm{T}$ content at the third position was $72.6 \%$, similar to what was reported for Alophila (8) and Panax schinseng Nees (1).

\section{Discussion}

\subsection{SSR in cpDNA}

Despite the high level of conservation in $\mathrm{cp}$ genome SSRs are evident as stated in previous reports (20) cpSSRs are useful in analysis of genetic diversity (26) due to their greater efficiency as opposed to genomic SSRs (26). Furthermore and due to the greater level of conservation, the information of the other species can be used to design specific primers for a species with unknown sequence data $(27,28,14)$.

\subsection{Gene Loss in Chloroplast}

During the course of evolution, loss and gain of genetic material have been noted for cpDNA. For instance $y c f 15$, a non-functional gene in other plants $(10,22,12)$ is also present in $G$. thurberi. The other example is inf $A$, most mobile gene between chloroplast and nuclear genome, that codes for a translation initial factor $1(29,30,31)$. In our study similar to cassava (19) G. hirsutum (18), the infA was absent. However, some others had the $\inf A$ as a pseudogene $(17,22)$, while in others infA appeared as an intact gene (21). Similar to G. hirsutum (18) and G. barbadense (17) and angiosperms, trnP-GGG was absent in G. thurberi. However, $\operatorname{trn} P-G G G$ was reported in Cryptomeria japonica (2). Thus it can be suggested that the gene has lost before the divergence of angiosperms. The other gene that worth considering was $r p l 22$ that codes for the large subunit of ribosomal protein 22 . $r p l 22$ is present in G. thurberi chloroplast genome similar to $G$. barbadense (17), but has been reported to be absent in G. hirsutum (18) and 3 legumes, namely Glycine, Lotus and Medicago (3). Therefore, its analysis may shed some light on the evolution of Gossypium.

\subsection{Extent of $I R$}

The border of the IR is usually different between species and the IR expansion and contraction are

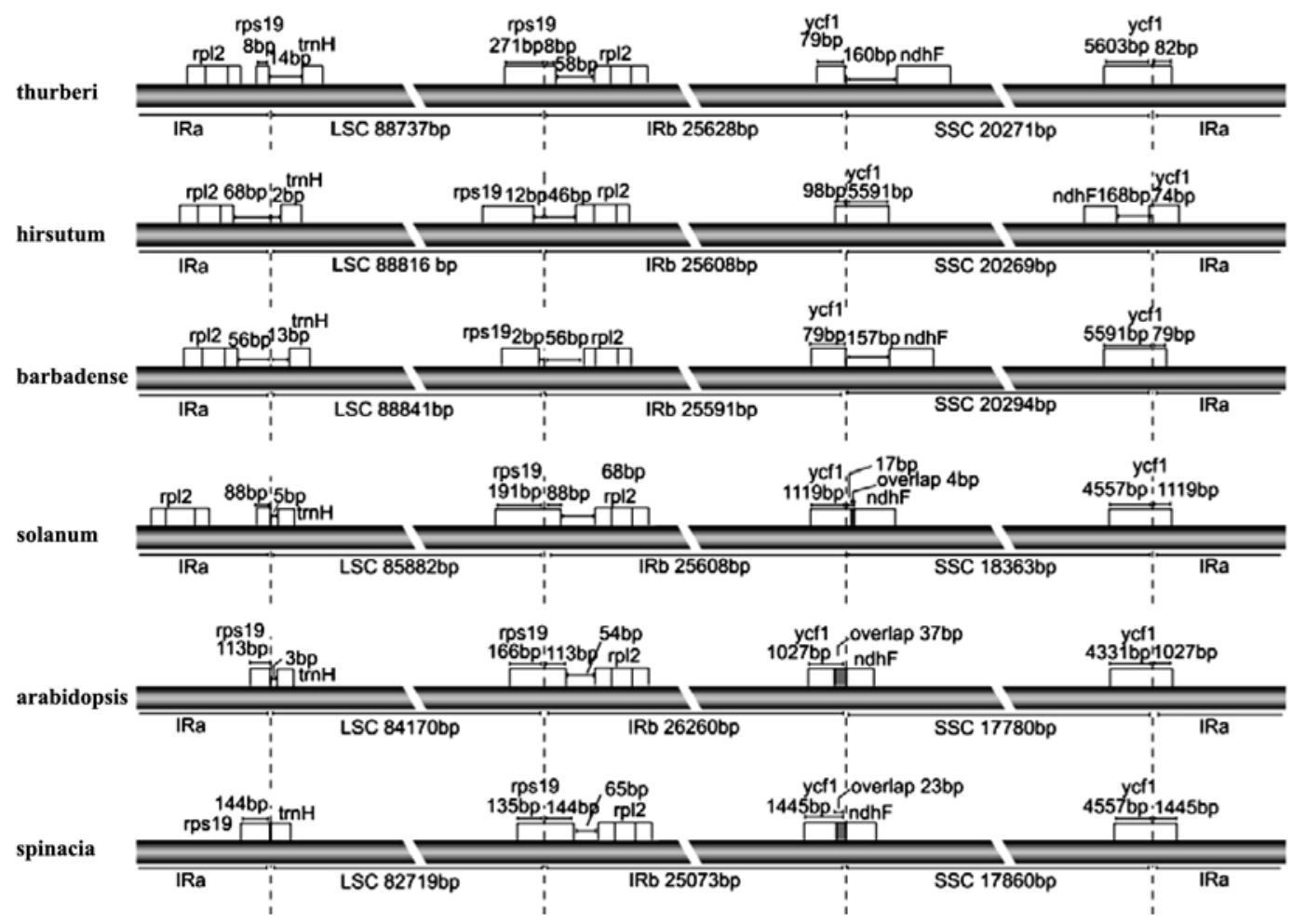

Figure 2. Comparison among LSC, IR and SSC border regions of three common reference species with studied genomes Note: all units of the sequence in the map is base pair 
Table 5. The comparison of introns among three cotton species; G. thurberi, G. hirsutum and G. barbadense

\begin{tabular}{lcccc}
\hline Intron & $\begin{array}{c}\text { G. } \\
\text { thurberi }\end{array}$ & $\begin{array}{c}\text { G. hirsu- } \\
\text { tum }\end{array}$ & $\begin{array}{c}\text { G. bar- } \\
\text { badense }\end{array}$ & $\begin{array}{c}\text { Sequence } \\
\text { identity }(\%)\end{array}$ \\
\hline trnK-UUU & 2534 & 2542 & 2535 & 98.37 \\
rps16 & 868 & 871 & 870 & 99.24 \\
trnG-UCC & 770 & 771 & 763 & 98.29 \\
atpF & 790 & 804 & 805 & 98.97 \\
rpoC1 & 741 & 753 & 753 & 99.42 \\
ycf3-1 & 777 & 777 & 777 & 99.61 \\
ycf3-2 & 789 & 789 & 789 & 100 \\
trnL-UAA & 583 & 575 & 582 & 98.80 \\
trnV-UAC & 606 & 618 & 609 & 97.85 \\
rps12_3end & 536 & 536 & 536 & 99.94 \\
clpP1 & 891 & 891 & 890 & 99.52 \\
clpP2 & 682 & 683 & 679 & 98.83 \\
petB & 760 & 760 & 761 & 99.52 \\
petD & 757 & 757 & 754 & 99,87 \\
rpl16 & 1138 & 1140 & 1135 & 99.50 \\
rpl2 & 693 & 695 & 688 & 99,52 \\
ndhB & 683 & 683 & 683 & 99.95 \\
trnl-GAU & 954 & 954 & 959 & 99.48 \\
trnA-UGC & 797 & 797 & 795 & 99.79 \\
ndhA & 1076 & 1076 & 1076 & 99.78 \\
\hline
\end{tabular}

important as far as genome size is concerned. IR expansion often leads to larger sizes of genome. Usually the pseudogenes are residing at the junction of IR and LSC/ SSC. The differences of the junctions among $G$. thurberi and five other species were analyzed (Figure 2).

The IRb/LSC junction was found within rps 19 in $G$. thurberi, Solanum lycopersicum, Arabidopsis thaliana and Spinacia oleracea, indicating that rps19 was duplicated at the junction at IRa and LSC. This duplication is very common in plants $(20,13)$. G. thurberi (8 bp) and Spinacia (144 bp) have the shortest and the longest duplications, respectively.

On the border of IRb and SSC, G. thurberi is similar with $G$. barbadense, having 79 bp of $y c f l$ fragment on the IRb border. Solanum, Arabidopsis and Spinacia have the same type of overlapping of $y c f l$ and $n d h F$ at the junction. The longest overlap is in Arabidopsis with $37 \mathrm{bp}$ and the shortest is in Solanum with $17 \mathrm{bp}$. The overlap is also found in Cucumis (20). The ycfl is located at the junction of SSC/IRb. So ycfl was duplicated in IRb at the border of IRb and SSC. In the Spinacia, ycfl has the longest duplication with 1445 bp. In G. thurberi and G. barbadense, ycfl has the shortest duplication with $79 \mathrm{bp}$. Gossypium hirsutum is in opposite direction of SSC as compared to other five speciesand therefore; $y c f 1$ is located at the junction of $\mathrm{IRb} / \mathrm{SSC}$ with $98 \mathrm{bp}$.

\subsection{Intron}

In the G. thurberi, 18 genes were found containing one or two introns, which is the same as in Panax schinseng Nees (1). In contrast to G. thurberi, introns were absent in rpoCl and clpP in $B$. Oldhamii and $D$. Latiflorus (13). The number and location of the intron in chloroplast seems to be conserved. The comparison (Table 5) of introns among G. thurberi, G. hirsutum and $G$. barbadense shows that 18 genes have one or two introns in the cp genome; 6 of which are tRNA coding genes and the rest are protein-coding genes. The longest intron is located in trnK-UUU with 2542 bp in $G$. thurberi, which is the only intron in cotton with another gene, $m a t K$, inside. The smallest intron is located in rpll2-3end with $536 \mathrm{bp}$, which is situated in IR. Genes of $y c f 3$ and $c l p P$ are located at LSC and are divided by two introns. Small variations among the introns were noted in three cotton species; intron lengths for $y c f 3-1, y c f 3-2, r p s 12 \_3$ end, $n d h B$ and $n d h A$

Table 6. GC content of G. thurberi chloroplast genome

\begin{tabular}{|c|c|c|c|c|c|c|c|c|c|c|c|}
\hline & \multicolumn{4}{|c|}{ coding region } & \multicolumn{3}{|c|}{ non-coding region } & \multirow[b]{2}{*}{$\begin{array}{c}\text { Complete } \\
\text { genome }\end{array}$} & \multirow[b]{2}{*}{ LSC } & \multirow[b]{2}{*}{ ssc } & \multirow[b]{2}{*}{ IR } \\
\hline & protein & trna & rrna & total & IGS & intron & total & & & & \\
\hline Length (bp) & 79740 & 2775 & 8970 & 91485 & 49915 & 20436 & 70351 & 160264 & 88737 & 20271 & 25628 \\
\hline proportion $\%$ & 49.76 & 1.73 & 5.60 & 57.08 & 31.15 & 12.75 & 43.90 & 100.00 & 55.37 & 12.65 & 15.99 \\
\hline $\mathrm{T} \%$ & 31.05 & 23.14 & 22.32 & 30.34 & 34.32 & 32.28 & 33.73 & 31.83 & 33.15 & 34.46 & 28.52 \\
\hline$A \%$ & 29.85 & 24.58 & 22.17 & 29.31 & 34.10 & 30.97 & 33.19 & 30.95 & 31.67 & 33.92 & 28.54 \\
\hline $\mathrm{C} \%$ & 19.28 & 26.13 & 27.79 & 20.56 & 15.99 & 19.12 & 16.90 & 18.99 & 18.11 & 16.54 & 20.66 \\
\hline $\mathrm{G} \%$ & 18.42 & 26.16 & 27.71 & 19.79 & 15.58 & 17.63 & 16.18 & 18.23 & 17.08 & 15.09 & 22.29 \\
\hline $\mathrm{A}+\mathrm{T} \%$ & 60.90 & 47.71 & 44.49 & 59.65 & 68.42 & 63.25 & 66.92 & 62.78 & 64.81 & 68.38 & 57.05 \\
\hline $\mathrm{C}+\mathrm{G} \%$ & 37.69 & 52.29 & 55.51 & 40.35 & 31.58 & 36.75 & 33.08 & 37.22 & 35.19 & 31.62 & 42.95 \\
\hline
\end{tabular}

Note: matK and gene overlaps are analyzed twice. IGS represents inter gene space 


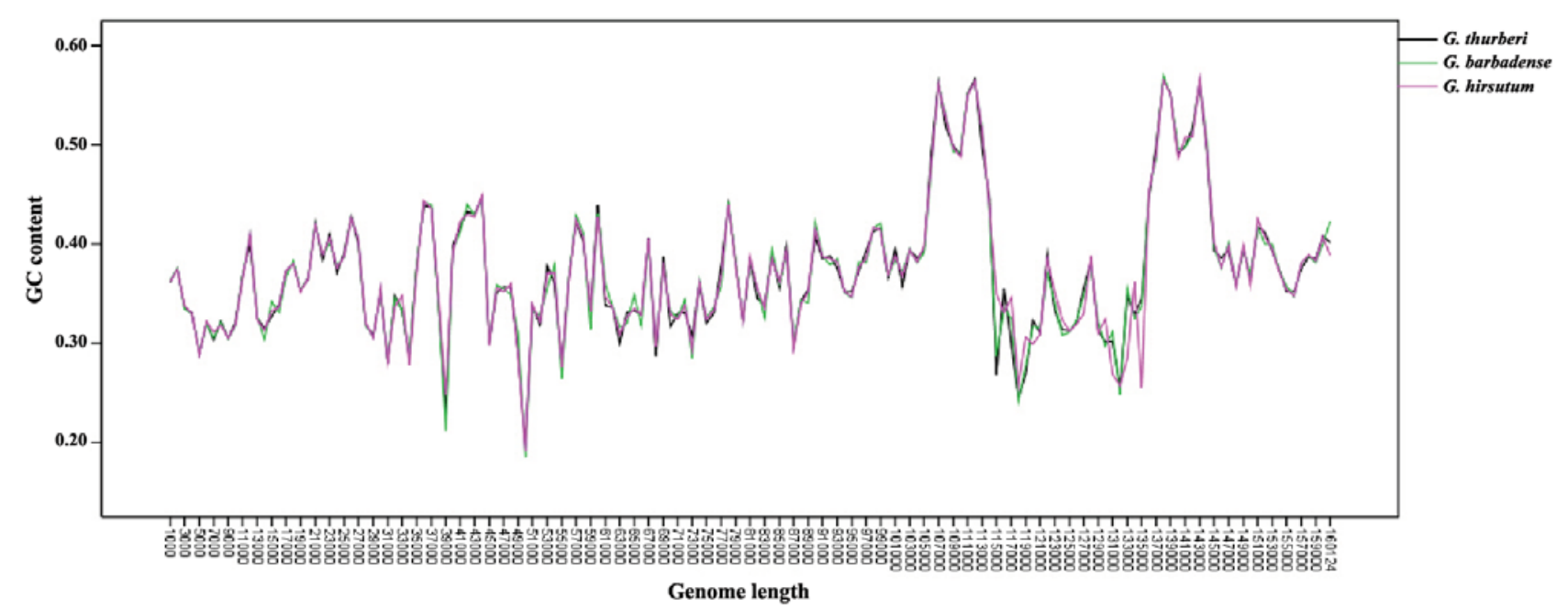

Figure 3. GC content of three Gossypium species (G. thurberi, G. hirsutum and G. barbadense)

are conserved, while the others have small variations. These intron sequences have a high identity, especially $y c f 3-2$ with a $100 \%$ sequence identity among the three cotton species.

\subsection{GC Content}

The GC content of $G$ thurberi cp genome is 37.22 $\%$, similar to other plants, such as $37.86 \%$ in Solanum lycopersicum, $37.85 \%$ in Nicotiana tabacum, $37.56 \%$ in Atropa belladonna, $37.25 \%$ in G. hirsutum and 34\% in Glycine max. Both coding and non-coding regions are low in GC content (32) with $40.35 \%$ and $33.08 \%$, respectively in $G$. thurberi. Variation in GC content among four different regions in $G$. thurberi cpDNA was observed (Table 6) and IR was the richest $(42.95 \%)$, similar to an earlier report (9). It is supposed that ribosomal genes (rrna4.5, rrna5, rrna16, rrna23) and coding regions $(19,8,10,5)$ are responsible for high GC content in IR. GC content distribution of the each region is similar with other species $(20,10,5)$. According to Gao (8) GC content was uneven across cp genome in Alsophila. In this study, we cut genomes of the three Gossypium species into $1 \mathrm{~kb}$-unit to compare uint to uint GC content across whole chloroplast genome. Our result showd that the distribution of GC is similar across the whole genome (Figure 3). At SSC region $G$. barbadense and $G$. thurberi are similar but different from G. hirsutum because of different direction of SSC. Across the whole genomes of the three cotton species, different fragments and even the adjacent fragments share different GC contents.

Gao (8) reported that GC contents in the chloro- plast genomes are not the same between genes in different functional groups; rRNA $(55.18 \%)>$ tRNA $(54.55 \%)>$ photosynthetic $(43.85 \%)>$ genetic system $(40.80 \%)>\mathrm{NADH}(39.54 \%)$. In G. thurberi, similar data was obtained. In the coding region, the rRNA genes have the highest GC content $(55.51 \%)$ and the protein genes have the lowest $(37.69 \%)$. In the noncoding region, GC content of IGS and intron is $31.58 \%$ and $36.75 \%$, respectively. The non-coding regions experienced a fast evolution, thus the non-coding region is richer in $\mathrm{GC}$ than coding regions.

$\mathrm{GC}$ content is an important feature of a genome that is correlated to the number of microRNA binding sites (33), functional elements physical location (34), recombination rate and gene distribution (35), organelle RNA editing (36) and gene expression regulation (37). GC content varies in the 5'UTR and $3^{\prime}$ UTR (34). GC content has a rare relationship with replication timing in human genome (38). GC content also have an effect on RNAi, because it is highly correlated to RNAi target site accessibility and negatively correlated with RNAi activity (39).

Low GC content is a significant feature of plastid genomes, which is possibly formed after endosymbiosis by DNA replication and repair (32). In viruses GC content is not dependent on genes constitution, but it is correlated with its location (40). Whether or not this exists in chloroplast genome needs more efferts on further studies.

\section{References}

1. Kim KJ, Lee HL. Complete chloroplast genome sequences from Korean ginseng (Panax schinseng Nees) and comparative 
analysis of sequence evolution among 17 vascular plants. DNA Res. 2004;11(4):247-261. DOI: 10.1093/dnares/11.4.247

2. Hirao T, Watanabe A, Kurita M, Kondo T, Takata K. Complete nucleotide sequence of the Cryptomeria japonica D. Don. chloroplast genome and comparative chloroplast genomics: diversified genomic structure of coniferous species. BMC Plant Biol. 2008;8:70. DOI: 10.1186/1471-2229-8-70

3. Saski C, Lee SB, Daniell H, Wood TC, Tomkins J, Kim HG, Jansen RK. Complete chloroplast genome sequence of Gycine max and comparative analyses with other legume genomes. Plant Mol Biol. 2005;59(2):309-322. DOI: 10.1007 /s11103-005-8882-0

4. Hallick RB, Hong L, Drager RG, Favreau MR, Monfort A, Orsat B, Spielmann A, Stutz E. Complete sequence of Euglena gracilis chloroplast DNA. Nucleic Acids Res. 1993;21(15):3537-3544. DOI: 10.1093/nar/21.15.3537

5. Young-Kyu Kim CWP, Ki-Joong K. Complete Chloroplast DNA Sequence from a Korean Endemic Genus,Megaleranthis saniculifolia, and Its Evolutionary Implications. Mol. Cells. 2009;27(3):365-381. DOI: 10.1007/s10059-009-0047-6

6. Ruf S, Karcher D, Bock R. Determining the transgene containment level provided by chloroplast transformation. Proc Natl Acad Sci USA. 2007;104(17):6998-7002. DOI: 10. 1073/pnas. 0700008104

7. Diekmann K, Hodkinson TR, Wolfe KH, van den Bekerom R, Dix PJ, Barth S. Complete chloroplast genome sequence of a major allogamous forage species, perennial ryegrass (Lolium perenne L.). DNA Res. 2009;16(3):165-176. DOI: 10.1093/dnares/dsp008

8. Gao L, Yi X, Yang YX, Su YJ, Wang T. Complete chloroplast genome sequence of a tree fern Alsophila spinulosa: insights into evolutionary changes in fern chloroplast genomes. BMC Evol Biol. 2009;9:130. DOI: 10.1186/1471-2148-9-130

9. Kim YK, Park CW, Kim KJ. Complete chloroplast DNA sequence from a Korean endemic genus, Megaleranthis saniculifolia, and its evolutionary implications. Mol Cells. 2009;27(3):365-381. DOI: 10.1007/s10059-009-0047-6

10. Mardanov AV, Ravin NV, Kuznetsov BB, Samigullin TH, Antonov AS, Kolganova TV, Skyabin KG. Complete sequence of the duckweed (Lemna minor) chloroplast genome: structural organization and phylogenetic relationships to other angiosperms. J Mol Evol. 2008;66(6):555-564. DOI: 10.1007/s00239-008-9091-7

11. Oliver MJ, Murdock AG, Mishler BD, Kuehl JV, Boore JL, Mandoli DF, Everett KD, Wolf PG, Duffy AM, Karol KG. Chloroplast genome sequence of the moss Tortula ruralis: gene content, polymorphism, and structural arrangement relative to other green plant chloroplast genomes. BMC Genomics. 2010;11:143-156. DOI: 10.1186/1471-2164-11-143

12. Tangphatsornruang S, Sangsrakru D, Chanprasert J, Uthaipaisanwong P, Yoocha T, Jomchai N, Tragoonrung S. The chloroplast genome sequence of mungbean (Vigna radiata) determined by high-throughput pyrosequencing: structural organization and phylogenetic relationships. DNA Res. 2010;17(1):11-22. DOI: 10.1093/dnares/dsp025

13. Wu FH, Kan DP, Lee SB, Daniell H, Lee YW, Lin CC, Lin NS, Lin CS. Complete nucleotide sequence of Dendrocalamus latiflorus and Bambusa oldhamii chloroplast genomes. Tree
Physiol. 2009;29(6):847-856. DOI: 10.1093/ treephys/tpp015

14. Yang M, Zhang X, Liu G, Yin Y, Chen K, Yun Q, Zhao D, Al-Mssallem IS, Yu J. The Complete Chloroplast Genome Sequence of Date Palm (Phoenix dactylifera L.). PLoS One. 2010;5(9):143-152. DOI: 10.1371/journal.pone.0012762

15. Lohse M, Drechsel O, Bock R. OrganellarGenomeDRAW (OGDRAW): a tool for the easy generation of high-quality custom graphical maps of plastid and mitochondrial genomes. Curr Genet. 2007;52(5-6):267-274. DOI: 10.1007/s00294007-0161-y

16. Kurtz S, Choudhuri JV, Ohlebusch E, Schleiermacher C, Stoye J, Giegerich R. REPuter: the manifold applications of repeat analysis on a genomic scale. Nucleic Acids Res. 2001; 29(22):4633-4642. DOI: 10.1093/nar/29.22.4633

17. Ibrahim RI, Azuma J, Sakamoto M. Complete nucleotide sequence of the cotton (Gossypium barbadense L.) chloroplast genome with a comparative analysis of sequences among 9 dicot plants. Genes Genet Syst. 2006;1(5):11-21. DOI: $10.1266 /$ ggs.81.311

18. Lee SB, Kaittanis C, Jansen RK, Hostetler JB, Tallon LJ, Town CD, Daniell H. The complete chloroplast genome sequence of Gossypium hirsutum: organization and phylogenetic relationships to other angiosperms. BMC Genomics. 2006;7:61. DOI: 10.1186/1471-2164-7-61

19. Daniell H, Wurdack KG, Kanagaraj A, Lee SB, Saski C, Jansen RK. The complete nucleotide sequence of the cassava (Manihot esculenta) chloroplast genome and the evolution of atpF in Malpighiales: RNA editing and multiple losses of a group II intron. Theor Appl Genet. 2008;116(5):723-737. DOI: $10.1007 / \mathrm{s} 00122-007-0706-y$

20. Kim JS, Jung JD, Lee JA, Park HW, Oh KH, Jeong WJ, Choi DW, Liu JR, Cho KY. Complete sequence and organization of the cucumber (Cucumis sativus L. cv. Baekmibaekdadagi) chloroplast genome. Plant Cell Rep. 2006;25(4):334-340. DOI: 10.1007/s00299-005-0097-y

21. Samson N, Bausher MG, Lee SB, Jansen RK, Daniell H. The complete nucleotide sequence of the coffee (Coffea arabica L.) chloroplast genome: organization and implications for biotechnology and phylogenetic relationships amongst angiosperms.Plant Biotechnol J. 2007;5(2):339-353. DOI: 10.1111/j.1467-7652.2007.00245.x

22. Steane D A. Complete nucleotide sequence of the chloroplast genome from the Tasmanian blue gum, Eucalyptus globulus (Myrtaceae). DNA Res. 2005;12(3):215-220. DOI: 10.1093/ dnares/dsi006

23. Wilson C A. Phylogeny of Iris based on chloroplast matK gene and trnK intron sequence data. Mol Phylogenet Evol. 2004;33(2):402-412. DOI: 10.1016/j.ympev.2004.06.013

24. Millen RS, Olmstead RG, Adams KL, Palmer JD, Lao NT, Heggie L, Kavanagh TA, Hibberd JM, Gray JC, Morden CW, Calie PJ, Jermiin LS, Wolfe KH. Many parallel losses of infA from chloroplast DNA during angiosperm evolution with multiple independent transfers to the nucleus. Plant Cell. 2001;13(3):645-658. DOI: 10.1105/tpc.13.3.645

25. Ohsako T, Ohnishi O. Nucleotide sequence variation of the chloroplast trnK/matK region in two wild Fagopyrum (Polygonaceae) species, F. leptopodum and F. statice. Genes Genet Syst. 2001;76(1):39-46. DOI: 10.1266/ggs.76.39 
26. Ribeiro M M, Mariette S, Vendramin GG, Szmidt AE, Plomion C, Kremer A. Comparison of genetic diversity estimates within and among populations of maritime pine using chloroplast simple-sequence repeat and amplified fragment length polymorphism data. Mol Ecol. 2002;11(5):869-877. DOI: 10.1046/j.1365-294X.2002.01490.x

27. Ishii $\mathrm{T}$, Mori $\mathrm{N}$, Takahashi $\mathrm{C}$, Ikeda $\mathrm{N}$, Kamijima O. Evaluation of allelic diversity at chloroplast microsatellite loci among common wheat and its ancestral species. Theor Appl Genet. 2001;103:9. DOI: 10.1007/s001220100715

28. Weising K, Gardner RC. A set of conserved PCR primers for the analysis of simple sequence repeat polymorphisms in chloroplast genomes of dicotyledonous angiosperms. Genome 1999;42(1):9-19. DOI: 10.1139/g98-104

29. Boynton JE, Gillham NW, Harris EH, Hosler JP, Johnson AM,Jones AR, Randolph-Anderson BL, Robertson D, Klein TM, Shark KB. Chloroplast transformation in Chlamydomonas with high velocity microprojectiles. Science 1988;240(4858):1534-1538. DOI: 10.1126/science. 2897716

30. Miller JT, Bayer RJ. Molecular phylogenetics of Acacia (Fabaceae: Mimosoideae) based on the chloroplast MATK coding sequence and flanking TRNK intron spacer regions. Am J Bot. 2001;88(4):697-705. DOI: 10.1071/SB01035

31. Sands JF, Cummings HS, Sacerdot C, Dondon L, GrunbergManago M, Hershey JW. Cloning and mapping of infA, the gene for protein synthesis initiation factor IF1. Nucleic Acids Res. 1987;15(13):5157-5168. DOI: 10.1093/nar/15.13.5157

32. Howe CJ, Barbrook AC, Koumandou VL, Nisbet RE, Symington HA, Wightman TF. Evolution of the chloroplast genome. Philos Trans $R$ Soc Lond B Biol Sci. 2003;358(1429):99-106. DOI: 10.1098/rstb.2002. 1176

33. Davis N, Biddlecom N, Hecht D, Fogel GB. On the relationship between GC content and the number of predicted microRNA binding sites by MicroInspector. Comput Biol
Chem. 2008;32(3):222-226. DOI: 10.1016/j.compbiolchem. 2008.02.004

34. Zhang L, Kasif S, Cantor CR, Broude NE. GC/AT-content spikes as genomic punctuation marks. Proc Natl Acad Sci USA. 2004;101(48):16855-16860. DOI: 10.1073/pnas.04078 21101

35. Freudenberg J, Wang M, Yang Y, Li W. Partial correlation analysis indicates causal relationships between GC-content, exon density and recombination rate in the human genome. BMC Bioinformatics. 2009;10Suppl 1: S66. DOI: 10.1186/ 1471-2105-10-S1-S66

36. Smith D R. Unparalleled GC content in the plastid DNA of Selaginella. Plant Mol Biol. 2009;71(6):627-639. DOI: 10. 1007/s11103-9545-3

37. Paterson AH, Curt L, Wendel JF. A rapid method for extraction of cotton (Gossypium spp.) genomic DNA suitable for RFLP or PCR analysis. Plant Molecular Biology Reporter. 1996;11:6-23. DOI: 10.1007/BF02670470

38. Watanabe Y, Abe T, Ikemura T, Maekawa M. Relationships between replication timing and GC content of cancer-related genes on human chromosomes $11 \mathrm{q}$ and $21 \mathrm{q}$. Gene 2009;433(1-2):26-31. DOI: 10.1016/j.gene.2008.12.004

39. Chan CY, Carmack CS, Long DD, Maliyekkel A, Shao Y, Roninson IB, Ding Y. A structural interpretation of the effect of GC-content on efficiency of RNA interference. BMC Bioinformatics. 2009,10Suppl 1:S33. DOI: 10.1186/14712105-10-S1-S33

40. Khrustalev VV, Barkovsky EV. Mutational pressure is a cause of inter- and intragenomic differences in GC-content of simplex and varicello viruses. Comput Biol Chem. 2009;33(4):295-302. DOI: 10.1016/j.compbiolchem.2009.06. 005

41. Wyman SK, Jansen RK, Boore JL. Automatic annotation of organellar genomes with DOGMA. Bioinformatics 2004;20 (17):3252-3255. DOI: 10.1093/bioinformatics/bth352 